\title{
Vegetation Cover Change and Its Diversity in Urban Areas of Medan
}

\section{Anita Zaitunah ( $\nabla$ anita@usu.ac.id)}

Universitas Sumatera Utara https://orcid.org/0000-0002-7131-1397

\section{Samsuri}

Universitas Sumatera Utara

\section{Fauziah Sahara}

Universitas Sumatera Utara

\section{Research Article}

Keywords: Change Detection, NDVI, Urban, Vegetation

Posted Date: May 17th, 2021

DOl: https://doi.org/10.21203/rs.3.rs-510164/v1

License: (c) (i) This work is licensed under a Creative Commons Attribution 4.0 International License. Read Full License 


\section{Abstract}

Vegetation plays an important role in maintaining the environmental quality of urban areas. Increase in population and development of cities has led to land conversion with lesser vegetated areas. Land cover change analysis in urban areas is needed, especially for urban regional planning with green open space consideration. This research was conducted to analyze urban vegetation cover and its changes in two sub-districts of Medan between the years 1999 and 2019. Normalized difference vegetation index (NDVI) and change analysis were conducted in the research. The diversity of plant within this areas was observed. The results showed changes in vegetation cover areas in the mentioned years. In 1999, most of the areas were under a highly dense vegetation class while in 2019, they were under a low-density vegetation class. This indicates a decrease in vegetation cover due to changes to non-vegetation cover or land cover areas with less vegetation. There are a diverse of plants within the area such as paddy, cassava, corn etc and also many tree species. It is recommended to optimize the land by replanting in the area with no or less vegetation to maintain the environmental quality.

\section{Introduction}

Urban areas are a place of more than half of the world's population. By 2050 , it is expected $66 \%$ of the population will be living in those areas. The continued population growth and urbanization have caused many problems that hamper environmental sustenance (Uçar et al 2020).

Cities as a mosaic of habitat that change through time. It shows environmental heterogeneity due to variation within and even among cities (Rivkin et al (2019). Guha et al (2020) mentioned the urban landscape is considered the most complex and heterogeneous landscape among the different land surface features.

Complex environmental problems have accompanied the enormous growth of cities. City environment is influenced by global and local climate changes, pollution from transport, industries, and local heating sources (Rozova et al 2020). Urbanization is considered as one of the main factors affecting global change. (Qing et al 2020). Climate change and urbanization are the two primary drivers that can alter vegetation growth processes in the urban environment (Li et al 2020).

The development of urban areas was led by the increase of population (Dewantoro 2020). It is in relation with the urbanization within the areas. It gives an impact to land cover change due to the need for housing and economical related actions. As Frimpong (2021) there are transformation of various Land Use Land Cover (LULC) types into urban/built-up areas due to rapid urbanization. Enoguanbhor (2019) has also mentioned that a significant contributor to land cover change is a rapid urban expansion.

Vegetation formations are an important component in the urban structure due to a wide range of ecosystem services in the area. Rozova et al. (2020) contested one of the important functions to improve the environmental and residential quality of the city is climate modification. 
Providing information on land cover and use change, including in vegetation areas, is a must for improving urban spatial planning in relation to the improvement of environmental quality. Remote sensing and geographic information systems are powerful scientific tools for supporting analysis and monitoring land use and land cover change. Sha et al. (2020) stated remote sensing systems provide valuable measurements to study changes in the various environmental factors. Further, they provide the means for observing regions. Remote sensing-based results indicated that vegetation conditions decrease significantly as the proportion of built-up land increase (Huang et al. 2020). To analyze land-use change and natural resource degradation and subsequently understand the relationship between the two processes, Saouli et al. (2021) mapped urban stain and vegetation cover using multi-temporal satellite images.

Landsat images have been used widely in urban studies. Many researches used the image for land use land cover detection and change analysis in remote sensing and GIS application. Those research including urban growth monitoring (Almazroui et al (2017); Bagan and Yamagata (2014); Al-Bilbisi (2019); Chen et al (2020); Dewantoro et al (2020); Frimpong (2021); Gala and Boakye (2020); Gbanie et al (2018); Goswami and Khire (2016); Ishtiaque et al (2017); Zhang et al (2020); Wang et al (2019); Mandal et al (2019); Mukherjee (2018)).

Medan is one of the major cities in Indonesia's that faces the same problem as any major city in the world. An increase in the city's population and development has led to the conversion of vegetated land for other purposes, especially settlements and buildings. Medan has 21 sub-districts with a total area of $265 \mathrm{~km}^{2}$. Each sub-district has its own area characteristics. Medan Baru and Medan Selayang subdistricts are among the areas that are overgrowing and experiencing many land cover changes, including increase in built-up areas and decrease in vegetation areas.

NDVI and change analysis were conducted in this research. The NDVI has been proven to accurately detect various land cover changes (Zaitunah et al. 2018). To detect changes in land cover and NDVI quickly and accurately, this research aimed to analyze the vegetation cover areas and its changes in Medan Baru and Medan Selayang's sub-district. Changes between the years 1999 and 2019 were analyzed. The NDVI is a powerful tool for understanding past vegetation, monitoring its current state, and predicting its future (Xing et al. 2020; Zaitunah et al. 2019; Samsuri et al. 2019). Phinzi and Szabo (2020) argued that the NDVI remains one of the most widely used tools to assess atmosphere and bare soil background through imagine spectral properties, facilitating image interpretability. It has been used for land use/built-up cover areas.

Zhang et al. (2020) found vegetation cover changes to be related to differences in urbanization rates, gross domestic products, population densities, and stages of urban development among the cities. Landuse change is one of the main impacts of human activities and profoundly impacts vegetation change (Wang et al. 2020). To ensure that ecosystem services are provided, vegetation cover should be considered in urban planning in urban core areas and peripheral areas (Zhang et al. 2020). Therefore, 
having information on vegetation cover change in urban areas will be useful in planning a better environment by assuring the optimal existence of green space within the areas.

\section{Materials And Methods}

The research was conducted in the sub-districts of Medan Baru and Medan Selayang (Figure 1). Processing and analysis of the research data were carried out in Forest Management Laboratory, Faculty of Forestry, Universitas Sumatera Utara.

Landsat images of the years 1999 and 2019 were downloaded through www.earthexplorer.usgs.gov. The software used for remote sensing and GIS analysis were Erdas Imagine 8.5 and ArcGIS 10.3. Ground check had been conducted in the research areas. Radiometric corrections were performed using Erdas 8.5 to correct errors that occurred in satellite imagery by sharpening the contrast. Image cropping was conducted to obtain a specific research location.

NDVI transformation was carried out using band infrared and red of Landsat. The principle of the NDVI is to measure the level of greenness. The intensity of greenness is correlated with the density of vegetation crown, which is related to leaf chlorophyll content. A comparison between the red $(R)$ reflectance and the near-infrared (NIR) parts of the electromagnetic spectrum was calculated. The selection of these wavelengths results from the absorption and reflection characteristics of vegetation. Due to absorption processes, especially in the red part of the electromagnetic spectrum, it was associated with the leaf chlorophyll content. In the near-infrared part of the electromagnetic spectrum, there is a very strong reflection that corresponds to multiple reflections in the leaf inner cell structure due to the cells' water content (Juergens and Meyer-Heß 2020).

The NDVI can estimate vegetation coverage. If the value of the NDVI is greater than others, this indicates that vegetation coverage is better (Wen and Zhang 2020). The more the NDVI value tends to +1 , the more it is related to vegetation cover and its vigor (Juergens and Meyer-Heß 2020). The value ranging between -1 to +1 resulting from this NDVI transformation has a different presentation on its land use. Clouds, water, and non-vegetation objects have the NDVI value of less than zero. The greater the value of the NDVI, the higher the density, and vice versa for a lower value. The following formula was used:

$$
\mathrm{NDVI}=\frac{\mathrm{IR}-\mathrm{R}}{\mathrm{IR}+\mathrm{R}}
$$

where,

$\mathrm{IR}=$ reflectance value of infrared band

$\mathrm{R}=$ reflectance value of the red band 
With the aid of NDVI transformation, information can be obtained on vegetation elements' existence in the whole area. The ground check gave valuable information on land use and land cover classes found in the field. So, we can obtain the range of values of the NDVI within some classes. The classification was conducted to divide the areas into different vegetation density classes. The range of values was defined by considering the vegetation existence in the field and the NDVI values. Phinzi and Szabo (2020) stated that different NDVI threshold values were used for classifying various land-use/cover classes (water bodies, badlands, bare soil, and built-up land, agriculture, grassland, and forest).

In this research, the location was classified into five classes, namely non-vegetation, low dense, medium dense, dense, and high dense classes. The classification can show the difference in vegetation density within the whole area (Zaitunah et al. 2018). In order to see the change in vegetation density, change analysis was conducted (Zaitunah et al. 2019, 2020). From the analysis, we were able to assess the change of vegetation cover within the observation years. This research provides information on the change of vegetation cover in any specific areas in the research location.

\section{Results And Discussion}

\subsection{Distribution of NDVI values in Medan Baru and Selayang Subdistricts}

The NDVI compares the total amount of visible red light absorbed with the amount of reflected nearinfrared light by a surface (Fusami et al. 2020). It basically uses a mathematical ratio to compare the amount of absorbed visible red light and the reflected near-infrared light.

Furthermore, Fusami et al. (2020) explained that negative values indicate areas with water, marshy surfaces, man-made structures, rocks, clouds, snow; bare land usually gives values that fall within $0.1-$ 0.2 while plants always have positive values ranging between 0.2 and 1 . For healthy, dense vegetation canopy, the values are above 0.5 while sparse vegetation has its values ranging from 0.2 to 0.5 . Generally, the NDVI values are between 0.2 and 0.4 for sparse vegetation areas and 0.4 and 0.6 for moderate vegetation, and anything above 0.6 indicates the highest possible green density. The distribution of the NDVI values in Medan Baru and Medan Selayang sub-districts in 1999 and 2019 can be seen in tables 1-

2.

In the year 1999, the Medan Baru and Medan Selayang sub-districts had the highest NDVI value in the range $>0.4$, which is 609.66 ha $(29.96 \%)$ of the total area, while the smallest in the range of $\mathrm{NDVI}<0.1$, which is 151.94 ha $(7.47 \%)$ of the total area (Table 1). These are quite different from the year 2019 (Table 2), which shows the NDVI of the Medan Baru and Medan Selayang subdistricts, where they had the highest NDVI value in the range of $0.1-0.2$. It comprised the area of 768.09 ha (37.73\%). The smallest NDVI range $>0.4$ covered 226.04 ha (11.1\%) of the total area. A comparison of each NDVI area class is illustrated in Figure 2.

Table 1. Distribution of the NDVI values in Medan Baru and Medan Selayang in 1999 


\begin{tabular}{|llll|}
\hline No & NDVI & Area $(\mathrm{Ha})$ & $\%$ Area \\
\hline 1 & $<0.1$ & 151.94 & 7.47 \\
\hline 2 & $0.1-0.2$ & 346.11 & 17.01 \\
\hline 3 & $0.2-0.3$ & 447.15 & 21.97 \\
\hline 4 & $0.3-0.4$ & 479.97 & 23.59 \\
\hline 5 & $>0.4$ & 609.66 & 29.96 \\
\hline Total & & $2,034.84$ & 100.00 \\
\hline
\end{tabular}

Table 2. Distribution of NDVI values in Medan Baru and Medan Selayang in 2019

\begin{tabular}{|llll|}
\hline No & NDVI & Area $(\mathrm{Ha})$ & Area $(\%)$ \\
\hline 1 & $<0.1$ & 243.47 & 11.96 \\
\hline 2 & $0,1-0,2$ & 768.09 & 37.73 \\
\hline 3 & $0,2-0,3$ & 468.48 & 23.02 \\
\hline 4 & $0,3-0,4$ & 329.43 & 16.18 \\
\hline 5 & $>0.4$ & 226.04 & 11.10 \\
\hline Total & & $2,035.50$ & 100.00 \\
\hline
\end{tabular}

Figure 3 shows the comparison of the NDVI values' distribution of the years 1999 and 2019. There are increasing areas with lower NDVI values in the whole area. Definitely, there is a decrease in areas with high values of NDVI. This means that there are prominent changes in vegetated areas to less or no vegetated areas.

Based on field checks, there are 9 land cover classes, namely buildings, roads, mixed gardens, oil palm, settlements, trees, grass, rice fields, and shrubs. The division of objects and the range of NDVI values can be seen in Table 3.

Table 3. NDVI values range of each land cover validated by ground check 


\begin{tabular}{|lll|}
\hline № & Class & NDVI Range \\
\hline 1 & Settlements & $0.04-0.28$ \\
\hline 2 & Road & $0.04-0.29$ \\
\hline 3 & Buildings & $0.06-0.29$ \\
\hline 4 & Mixed Garden & $0.24-0.50$ \\
\hline 5 & Grass & $0.26-0.44$ \\
\hline 6 & Trees & $0.26-0.52$ \\
\hline 7 & Rice fields & $0.30-0.46$ \\
\hline 8 & Shrubs & $0.30-0.52$ \\
\hline 9 & Oilpalm & $0.45-0.49$ \\
\hline
\end{tabular}

Human activities have led to land-use change with a strong influence on the existence of vegetated land. Land-use changes driven by human activities are a consequence of any development. Wang et al. (2020) mentioned farmland, forest land, and grassland are converted to construction land due to urban expansion along with economic and social development. Furthermore, Wang et al. (2020) highlighted the contribution of the NDVI in studying the impacts of land-use change on vegetation.

In the sub-district of Medan Baru and Medan Selayang, the NDVI value range lies between 0.04-0.49. Based on ground check, there are land covers in each range of the NDVI. Land cover with the NDVI value less than 0.1 to 0.2 are building areas, roads, and settlements while land cover with the NDVI value 0.20.4 are mixed gardens, land with trees, grass, rice fields and shrubs. There is more dense vegetation in the area with NDVI values higher than 0.4 , including oil palm, trees, and shrubs. Visualization of each land cover can be seen in figures 4 .

The denser the vegetation, the higher the NDVI value. The low the NDVI value will represent the low vegetation density. There are variations of the NDVI values in each land cover class due to the variation of objects found in the field; for example, there are trees alongside the road and trees in between houses in settlement areas. Some trees can also be found near buildings, and some near rice fields, grass land, and shrub. The higher the NDVI values found in areas with trees, shrub and oil palm. The lower value is found in settlements and roads.

The spatial resolution of Landsat images contributes to the variation of NDVI values of each land cover classes as there are many objects found in areas of $30 \mathrm{~m}$. There is also due to existence of vegetation in each land cover classes as mentioned above.

\subsection{Vegetation Existence in Medan Baru and Selayang Subdistricts}


Based on the finding in the field and some references in the classification of NDVI (Lufilah et al (2017), Mukhoriyah et al (2019), Irawan and Sirait (2018)), the vegetation density class was divided into five classes: the non-vegetation class with an NDVI value $<0.1$, a low dense class with an NDVI value of $0.1-$ 0.2 , medium dense with NDVI values of $0.2-0.3$, dense class NDVI value of $0.3-0.4$, and high dense class with NDVI values of $>0.4$.

\section{Non-Vegetation Class}

Non-vegetation classes are roads, dense settlements, and tall buildings. There is little or no vegetation in this class. The non-vegetation class consists of residential areas, business areas represented by tall buildings near the main road, and congested streets in the flyover area. Some campus areas of the University of North Sumatra, which is located in Medan Baru, show non-vegetation density classes. The library, faculty building, and administration office center building belong to this class. Areas that belong to the non-vegetation class illustrated in Figure 5.

\section{Low Dense Class}

In the low dense class, the vegetation density is low. Areas that belong to this class are roads, buildings, settlements, and bare lands with less vegetation. Low dense class is found in some areas in the city surrounded by buildings and existing vegetation. There are also trees along the path of the road and around houses. The species found here are Plumeria rubra, Mangifera indica, Pterocarpus indicus, Gnetum gnemon, Polyalthia longifolia, and Areca catechu. In the campus area of the Universitas Sumatera Utara (USU), there are some buildings with trees around them. The species found here are Terminalia catappa, Casuarina equisetifolia, Mangifera indica, and Ficus benjamina. Areas that belong to the low dense class can be seen in Figure 6.

\section{Medium Dense Class}

In the medium dense class, the density of vegetation is rather high. There are roads, buildings, and settlements, where those covers have vegetation; for example, individual trees near those covers.

Medium dense class is found in settlements with a large yard with various trees. There are also gardens in the area of settlement. The research identified Leucaena leucocephala, Solanum melongena, Vigna unguiculata, Musa paradisiaca, Manihot esculenta, Mangifera indica, Theobroma cacao, Morinda citrifolia, and Artocarpus heterophyllus. It also includes a city park with trees such as Swietenia mahagoni, Pterocarpus indicus, Leucaena leucocephala, Adenanthera pavonina, Polyalthia longifolia, Mangifera indica, Mimusops elengi, Artocarpus altilis, Plumeria rubra, Nephelium lappaceum, Delonix regia), Gnetum gnemon, Cocos nucifera, and Annona muricata. In the campus area of the USU, library parks and some faculties have areas with trees. The species found here are Swietenia mahagoni, Polyalthia longifolia, Filicium decipiens, Pinus merkusi, Mimusops elengi, Alstonia scholaris, and Syzygium aqueum. Areas that belong to the medium dense class can be seen in Figure 7 . 
In the dense class, rice fields, shrubs, trees, and mixed gardens were found. People grows cassava, sugar cane, corn, banana and oranges. Trees are found around the areas. The dense class includes shrubs, grasses, and trees such as Gnetum gnemon, Durio zibethinus, Swietenia mahagoni, Ficus benjamina, Tectona grandis, Mangifera indica, and Tamarindus indica. In some areas, community-owned gardens belong to this class with species such as Musa paradisiaca, Zea mays, Saccharum ficinarum, Carica papaya, Vigna unguiculataArachis hypogaea, and Cocos nucifera. There is a mini-stadium, saga park, auditorium park, and research farmland in the USU campus area. The research found many tree species. The tree species are Annona muricata, Durio zibethinus, Artocarpus heterophyllus, Persea americana, Psidium guajava, Tamarindus indica, Mangifera indica, Ficus benjamina, Mimusops elengi, Leucaena leucocephala, Polyalthia longifolia, Terminalia catappa, Areca catechu, Adenanthera pavonina, Pinus merkusii, Swietenia mahagoni, Aleurites molucana, Pometia pinnata, Syzygium aqueum, Hylocereus undatus, Carica papaya, and Nephelium lappaceum. Areas that belong to the dense class can be seen in Figure 8.

\section{High Dense Class}

While in high dense, there are dense vegetation found including trees, oil palm, rice fields, very dense shrubs, and mixed gardens. High dense class includes land overgrowing with trees accompanied by shrubs, land planted with oil palm, vast rice fields, and mixed gardens owned by the community planted with various plants such as Citrus nobilis, Zea mays, Cymbopogon citratus, Solanum torvum, Artocarpus altilis, Saccharum officinarum, Cocos nucifera, Etlingera elatior, Theobroma cacao, Carica papaya, Manihot esculenta, Musa paradisiaca, and Psidium guajava. The high dense class was found in the campus forest which is consisting of some species. The species are Swietenia mahagoni, Artocarpus heterophyllus, Psidium guajava, Paraserianthes falcataria. In USU administration center park is also found Terminalia catappa, Terminalia mantaly, Ficus elastica, Swietenia mahagoni, Syzygium oleana, Ficus benjamina, Durio zibethinus, and Pterocarpus indicus. Areas that belong to the high dense class can be seen in Figure 9.

The increase of population growth and development of the Medan areas as a big city has increased builtup areas and settlements. It decreases vegetated land. Changes in rice fields and gardens into housing areas are examples of conversion. The ground check shows dense settlements and multi-storey buildings are found more than vegetated lands such as trees, rice fields, and community-owned gardens. The decrease in vegetation areas could have a bad impact on the quality of the environment, i.e., problems of flood due to a decrease in water absorption areas.

Many vegetated lands were converted into housing and buildings. Moreover, some vegetation areas were replaced by roads and public facilities. Vegetation cover changes could lead to environmental problems, such as the incident of flood in the rainy season, bad air quality due to pollution, and health problems. In urban contexts, vegetation surfaces are very important for the well-being and health of the urban population. The NDVI is often correlated with socioeconomic and/or sociodemographic data to 
demonstrate the inequality in environmental settings that themselves influence individual health and questions of environmental justice (Juergens and Meyer-Heß 2020).

Medan has faced some flood incidents, especially in the areas near the river. Some of the areas have no or less vegetation on the side of the river. This situation can worsen unless there is an improvement of areas by replanting trees and better planning the areas. This requires preparing both the community and land condition. Land-use planning process was used to provide alternative and possible land uses as well as management activities to ensure land-use sustainability (Samsuri et al. 2019). It is necessary to initiate efforts and actions to preserve the environment to prevent further damage. Four criteria were used for determining suitable plants that could be planted as well as cultivated by the community: plant species found in natural forests near the city, plant species meeting physical and soil characteristics, plant species cultivated by the community, and plant species based on community perceptions (Samsuri et al. 2019).

The fast population growth and the significant exploitation of natural resources imply great modifications in the environment, causing environmental impacts, including the average temperature increase of the Earth. Understanding the effects of changing land cover allows greater agility in public managers' decision to mitigate the effects of urban heat and the formation of heat islands by vegetation insertion in densely occupied areas (Pessi et al. 2020).

Many problems in urban areas need a serious attention such as pollution (Arsovski et al 2018, Jorquera et al 2019, Zhou et al 2018a, Yang et al 2020, Twisa et al 2020, Dardouri and Sghaier 2019, Qu et al 2019), environmental pollution and health (Yang 2020), urban water security (Hoekstra et al 2018, Twisa et al 2020).

Urban vegetation has an important role in ensuring the ecological security of cities. Rapid urbanization in China has radically changed the urban vegetation cover. Isolation of the contributions of human activities from the observed vegetation can help understand the effects of human activities on urban ecosystems (Wan and Gao 2020).

The research shows big changes in vegetated areas into other land uses as the field check found the existence of built areas in the city. Settlements and buildings with no or less vegetation are prominent. $\mathrm{NDVI}$ analysis shows the change of dense vegetation class into the lower class, especially the change into non-vegetation and the low density class.

A big part of the urban land occupation is composed of a highly dense buildings and large paved and impermeable areas, which support the high increase in the air temperature in urban centers, which creates microclimates in different zones of the city, causing heat islands (Giacomelli et al. 2020).

In that case, the modeling of the urban sprawl effect on vegetation-cover is realized by the NDVI) After observing and characterizing the areas altering by the urban expansion, the results displayed that in 17 years, the urban growth of Annaba decreased the vegetation cover by $28.50 \%$ (Saouli et al. 2021). 
Urban studies shows wide scope of discussion with the same aim that is to overcome problems and built a good environment for man and nature. Such studies including study on urban resilience (Ribeiro et al 2019, Bush and Doyon (2019). Issues on building a smart sustainable cities are also among those studies (Garau et al 2018, Kociuba and Maj (2020), (Tang and Lee (2016). There are also studies on urbanization strategy and planning (Han et al 2018, Huayi et al 2020, Guzal-Dec et al 2020), insights for the future of urban ecosystem services research (Kremer et al 2016).

Paying attention to the construction of green space and green roads in cities, reducing urban land use, rationally distributing land resources, and strengthening environmental management and protection are important ways to improve the ecological environment level of vegetation in Zaozhuang City (Wen and Xhang 2020). The research confirmed the importance of vegetation structures in the process of mitigating urban climate extremes and improving environmental quality (Rozova et al. 2020). The development of fringe areas outside the urban core areas should be avoided as much as possible to mitigate vegetation degradation effectively, and the positive influences of urbanization on vegetation growth through effective urban landscape planning should be encouraged (Li et al. 2020). The research provides information on vegetation's condition by giving information on the location and the density of vegetation within the area. It is a valuable information for urban planning to achieve the highest quality of the environment and supporting the health of the community.

\section{Conclusions}

The research found a decrease of high and dense vegetation areas into lower and non-vegetated areas within 20 years. This indicates a decrease in vegetation cover due to changes to non-vegetation cover or land cover areas with less vegetation. The NDVI could further explore the change of vegetation cover in urban areas and take part in monitoring and urban planning. In the research area, it is recommended to optimize the land by replanting the area with no or less vegetation and maintaining the vegetated areas to improve the environmental quality.

\section{Declarations}

\section{Acknowledgements}

The authors would like to thank the Directorate of Research and Community Service (DRPM) for supporting the funding of this basic research for the year 2020. The author also thanks Universitas Sumatera Utara for the support as well.

\section{Funding}

This work was supported by Directorate of Research and Community Service (DRPM) of Indonesia.

\section{Conflict of Interests}


The authors declare no conflict of interests.

\section{Availability of data and material}

All data generated or analyzed in this study appear in the submitted article.

\section{References}

1. Al-Bilbisi $H$ (2019) Spatial monitoring of urban expansion using satellite remote sensing images: $A$ case study of Amman City, Jordan. Sustainability (Switzerland), 11(8). DOI:10.3390/su11082260

2. Almazroui M, Mashat A, Assiri ME, Butt MJ (2017) Application of Landsat Data for Urban Growth Monitoring in Jeddah. December 2017 Earth Systems Environment 1(2) DOI:10.1007/s41748-0170028-4

3. Arsovski S, Kwiatkowski M, Lewandowska A, Jordanova Peshevska D, Sofeska E, Dymitrow M (2018) Can urban environmental problems be overcome? The case of Skopje-world's most polluted city. Bulletin of Geography Socio-economic Series 40(40):17-39. DOl:http://dx.doi.org/10.1515/bog2018-0012

4. Bagan $\mathrm{H}$, Yamagata $\mathrm{Y}$ (2014) Land-cover change analysis in 50 global cities by using a combination of Landsat data and analysis of grid cells. Environmental Research Letters, 9(6). DOI:10.1088/17489326/9/6/064015

5. Bush J, Doyon A (2019) Building urban resilience with nature-based solutions: How can urban planning contribute? Cities, 95. DOI: 10.1016/j.cities.2019.102483

6. Chen THK, Qiu C, Schmitt M, Zhu XX, Sabel CE, Prishchepov A (2020) Mapping horizontal and vertical urban densification in Denmark with Landsat time-series from 1985 to 2018: A semantic segmentation solution. December 2020 Remote Sensing of Environment 251. DOI:

10.1016/j.rse.2020.112096

7. Dardouri S, Sghaier J (2019) Modeling atmospheric emissions during olive husk drying and study of meteorological factors effect in the vicinity of urban areas. Journal of King Saud University - Science 31(4):635-641. DOI:10.1016/j.jksus.2019.06.004

8. Dewantoro BEB, Natani PA, Islamiah Z (2020) Spatial Monitoring of Urban Development Direction Using Landsat 7 ETM + and Landsat 8 OLI/TIRS in Balikpapan City, Indonesia. International Journal of Innovative Technology and Exploring Engineering (IJITEE) ISSN: 2278-3075, Volume-9 Issue-4, February 2020 2703. February 2020 DOI: 10.35940/ijitee.D1893.029420

9. Enoguanbhor EC, Gollnow F, Nielsen JO, Lakes T, Walker BB (2019) Land cover change in the Abuja City-Region, Nigeria: Integrating GIS and remotely sensed data to support land use planning. Sustainability (Switzerland), 11(5). DOI:10.3390/su11051313

10. Frimpong B (2021) Tracking Urban Expansion Using Random Forests for the Classification of Landsat Imagery (1986-2015) and Predicting Urban/Built-Up Areas for 2025: A Study of the Kumasi Metropolis, Ghana January 2021Land 10(44) DOI:10.3390/land10010044 
11. Fusami AA, Nweze OC, Hassan R (2020) Comparing the effect of deforestation result by NDVI and SAVI. International Journal of Scientific Research Publications (IJSRP) 10(06):918-925. doi:10.29322/IJSRP.10.06.2020.p102110

12. Gala T, Boakye $L$ (2020) Spatio temporal analysis of remotely sensed Landsat time series data for monitoring 32 years of urbanization. June 2020Journal of Human Capital 5(2):85-98. DOI:10.22034/IJHCUM.2020.02.01

13. Garau C, Pavan VM (2018) Evaluating urban quality: Indicators and assessment tools for smart sustainable cities. Sustainability (Switzerland), 10(3). DOI:10.3390/su10030575

14. Gbanie SP, Griffin AL, Thornton A (2018) Impacts on the urban environment: Land cover change trajectories and landscape fragmentation in post-war Western Area, Sierra Leone. Remote Sensing, 10(1) DOI:10.3390/rs10010129

15. Giacomelli B, Padilha JC, Renata P, Mantovani A, Eckert NH (2020) Influence of Vegetation in the Creation of Urban Microclimates. In book: Climate Change, Hazards and Adaptation Options. doi: 10.1007/978-3-030-37425-9_8

16. Goswami M, Khire MV (2016) Land Use and Land Cover Change Detection for Urban Sprawl Analysis of Ahmedabad City using Multitemporal Landsat Data. International Journal of Advanced Remote Sensing GIS 5(1):1670-1677. DOI:10.23953/cloud.ijarsg.51

17. Guha S, Govil H, Monika (2020) An investigation on seasonal variability between LST and NDWI in an urban environment using Landsat satellite data An investigation on seasonal variability between LST and NDWI in an urban environment using Landsat satellite data. July 2020Geomatics. Natural Hazards Risk 11(1):1319-1345. DOl:https://doi.org/10.1080/19475705.2020.1789762

18. Guzal-Dec D, Zbucki $Ł$, Kuś A (2020) Good governance in strategic planning of local development in rural and urban-rural gminas of the eastern peripheral voivodeships of Poland. Bulletin of Geography Socio-economic Series 50(50):101-112. DOI:http://dx.doi.org/10.1515/19924

19. Han L, Zhou W, Li W, Qian Y (2018) Urbanization strategy and environmental changes: An insight with relationship between population change and fine particulate pollution. Sci Total Environ 642:789-799. DOl:10.1016/j.scitotenv.2018.06.094

20. Hoekstra AY, Buurman J, Van Ginkel KCH (2018, May 1) Urban water security: A review. Environmental Research Letters. Institute of Physics Publishing. DOI: 10.1088/1748-9326/aaba52

21. Huang B, Li Z, Dong C, Zhu Z, Zeng H (2020) Effects of urbanization on vegetation conditions in coastal zone of China. December 2020. Progress in Physical Geography: Earth Environment. DOI:10.1177/0309133320979501

22. Huayi Wu ZG, Zelong Y (2020) Geospatial big data for urbanplanning and urban management. Geospatial Information Science 23(4):273-274. DOI:10.1080/10095020.2020.1854981

23. Irawan S, Sirait J (2018) PERUBAHAN KERAPATAN VEGETASI MENGGUNAKAN CITRA LANDSAT 8 DI KOTA BATAM BERBASIS WEB. Jurnal Kelautan: Indonesian Journal of Marine Science Technology, 10(2), 174. https://doi.org/10.21107/jk.v10i2.2685 
24. Ishtiaque A, Shrestha M, Chhetri N (2017) Rapid urban growth in the kathmandu valley, nepal: Monitoring land use land cover dynamics of a himalayan city with landsat imageries. Environments MDPI 4(4):1-16. DOI:10.3390/environments4040072

25. Jorquera H, Montoya LD, Rojas NY (2019) Urban air pollution. In Urban Climates in Latin America (pp. 137-165). Springer International Publishing. DOI: 10.1007/978-3-319-97013-4_7

26. Juergens C, Meyer-Heß MF (2020) Application of NDVI in environmental justice, health and inequality studies - potential and limitations in urban environments. DOI: 10.20944/preprints202008.0499.v1

27. Kociuba D, Maj M (2020) Walkable city and universal design in theory and practice in Poland. Bulletin of Geography Socio-economic Series 50(50):113-132. DOl:http://dx.doi.org/10.1515/30838

28. Kremer, P., Hamstead, Z., Haase, D., McPhearson, T., Frantzeskaki, N., Andersson,E., ... Elmqvist, T. (2016). Key insights for the future of urban ecosystem services research. Ecology and Society, 21(2). DOI: $10.5751 /$ ES-08445-210229

29. Li D, Wu S, Liang Z, Li S (2020) The impacts of urbanization and climate change on urban vegetation dynamics in China. Urban Forestry Urban Greening 54:126764. DOI:10.1016/j.ufug.2020.126764

30. Lufilah SN, Makalew AD, Sulistyantara B (2017) PEMANFAATAN CITRA LANDSAT 8 UNTUK ANALISIS INDEKS VEGETASI DI DKI JAKARTA. Jurnal Lanskap Indonesia, 73-80. https://doi.org/10.29244/jli.2017.9.1.73-80

31. Mandal J, Ghosh N, Mukhopadhyay A (2019) Urban Growth Dynamics and Changing Land-Use LandCover of Megacity Kolkata and Its Environs. J Indian Soc Remote Sens 47(10):1707-1725. DOI:10.1007/s12524-019-01020-7

32. Mukherjee S, Bebermeier W, Schütt B (2018, September 1) An overview of the impacts of land use land cover changes (1980-2014) on urban water security of Kolkata. Land. MDPI AG. DOI: 10.3390/land7030091

33. Mukhoriyah M, Sari NM, Sharika M, Hanifati LN (2019) Identifikasi Ketersediaan Ruang Terbuka Hijau Kecamatan Kramat Jati Kodya Jakarta Timur Menggunakan Citra Pleiades. Jurnal Planologi 16(2):158. https://doi.org/10.30659/jpsa.v16i2.5005

34. Pessi DD, Pimentel CF, Alves AKA, Miranda PL, da Silva NM (2020) Analysis of the relationship between NDVI and land surface temperature as a technique in the urban planning of the counties. Project: Restauração ecológica e geotecnologias como instrumentos para aperfeiçoar o plano de recuperação de áreas degradadas (PRAD) de Mato Grosso. doi: 10.5212/TerraPlural.v.13i3.0016

35. Phinzi K, Szabo S (2020) NDVI-based land-use/cover change detection in a mountainous heterogeneous landscape. November 2020. Conference: Az Elmelet es a Gyakorlat Talalkozasa a Terinformatikaban XI Theory Meets Practice in GIS at: Debrecen, Hungary

36. Qing L, Petrosian HA, Fatholahi SN, Chapman M, Li J (2020) Quantifying Urban Expansion Using Landsat Images and Landscape Metrics: A Case Study of the Halton Region, Ontario. November 2020Geomatica. DOI: 10.1139/geomat-2020-0017

37. Qu, C., Albanese, S., Lima, A., Hope, D., Pond, P., Fortelli, A., ... De Vivo, B. (2019). The occurrence of OCPs, PCBs, and PAHs in the soil, air, and bulk deposition of the Naples metropolitan area, southern 
Italy: Implications for sources and environmental processes. Environment International, 124, 89-97. DOI: 10.1016/j.envint.2018.12.031

38. Ribeiro PJG, Pena J, Gonçalves LA (2019, October 1) Urban resilience: A conceptual framework. Sustainable Cities and Society. Elsevier Ltd. DOI: 10.1016/j.scs.2019.101625

39. Rivkin LRSantangeloJSAlbertiMAronsonM, F.de Keyzer C, W.Diamond S, E.Fortin M, J.Frazee L, J.Gorton AJHendryAP (2019) .Liu Y.Losos J. B.Maclvor J. S.Martin R. A.McDonnell M. J.Miles L. S.Munshi-South J.Ness R. W.Newman A. E.Stothart M. R.Theodorou P.Thompson K. A.Verrelli B. C.Whitehead A.Winchell K. M.Johnson M. T. A roadmap for urban evolutionary ecology. Evol Appl. DOI:10.1111/eva.12734

40. Rozova D, Supuka J, Klein J, Jasenka M, Totha A, Stefl L (2020) Effect of vegetation structure on urban climate mitigation. Acta Horticulturae et Regiotecturae 23(2):60-65. DOI:10.2478/ahr-20200013

41. Samsuri, Ahmad AG, Zaitunah A, Tambusai HK (2019) Evaluation of plant species suitability for lowland forest landscape restoration in Lepan watersheds, Langkat district, north Sumatra, Indonesia. Biodiversitas 20(10):2903-2909. doi:10.13057/biodiv/d201018

42. Samsuri, Elfiati D, Siregar OS (2019) Land suitability evaluation for forestry plants in Tao Lake, Padang Lawas Utara District, North Sumatra. In IOP Conference Series: Earth and Environmental Science (Vol. 365). Institute of Physics Publishing. DOI: 10.1088/1755-1315/365/1/012011

43. Samsuri ZA, Siregar HI. Analysis of vegetation density change in coastal villages of Tapanuli Tengah and Sibolga using landsat images. IOP Conference Series Earth and Environmental Science 374:012059. doi: 10.1088/1755-1315/374/1/012059

44. Saouli RA, Benhassine N, Oularbi A (2021) Modeling the urban sprawl effect on vegetation-cover in Annaba. Journal of Fundamental Applied Sciences 13(1):618-633. DOl:10.4314/jfas.v13i1.32

45. Sha K, Srinivasa A, Madhu D (2020) The study on variability of NDVI over Kerala using satellite observations November 2020. AIP Conference Proceedings 2287(1):020013. Conference: 16th International Conference on Concentrator Photovoltaic Systems (CPV-16). DOI: 10.1063/5.0029907

46. Tang HT, Lee YM (2016) The making of sustainable urban development: A synthesis framework. Sustainability (Switzerland) 8(5):1-28. DOI:10.3390/su8050492

47. Twisa S, Mwabumba M, Kurian M, Buchroithner MF (2020) Impact of land-use/land-cover change on drinking water ecosystem services in Wami River Basin, Tanzania. Resources, 9(4).

DOI:10.3390/RESOURCES9040037

48. Ucar Z, Akay AE, Bilici E. November (2020) Towards green smart cities: importance of urban forestry and urban vegetation. The International Archives of the Photogrammetry, Remote Sensing and Spatial Information Sciences, Volume XLIV-4/W3-2020. DOI: 10.5194/isprs-archives-XLIV-4-W3-2020399-2020

49. Wan Z, Gao W (2020) Changes in urban vegetation cover and analysis of the influencing factors: a case study of Harbin, Heilongjiang Province, China. October 2020. Arab J Geosci 13(19):1053. doi:10.1007/s12517-020-05931-5 
50. Wang F, Liu XK, Liu X, Li Y, Wang T (2020) Impacts of land use change on NDVI in Shaanxi Province of China IOP conf. Series: Earth Environmental Science 508:012086. DOI:10.1088/1755-

$1315 / 508 / 1 / 012086$

51. Wang SW, Gebru BM, Lamchin M, Kayastha RB, Lee WK (2020) Land use and land cover change detection and prediction in the kathmandu district of nepal using remote sensing and GIS. Sustainability (Switzerland), 12(9). DOI:10.3390/su12093925

52. Wen B, Zhang J (2020) Ecological environment evaluation of vegetation in Zaozhuang City based on Landsat-8. IOP Conf Ser: Earth Environ Sci 508:012114. DOI:10.1088/1755-1315/508/1/012114

53. Xing X, Yan CZ, Jia Y, Jia H, Lu J, Luo G (2020) An effective high spatiotemporal resolution NDVI fusion model based on histogram clustering November 2020. Remote Sensing 12(22):3774. DOI:10.3390/rs12223774

54. Yang J, Shi B, Shi Y, Marvin S, Zheng Y, Xia G (2020) Air pollution dispersal in high density urban areas: Research on the triadic relation of wind, air pollution, and urban form. Sustainable Cities Society, 54. DOI:10.1016/j.scs.2019.101941

55. Yang $T$ (2020) Association between perceived environmental pollution and health among urban and rural residents-a Chinese national study. BMC Public Health, 20(1). DOI:10.1186/s12889-020-8204-0

56. Zaitunah A, Ras S, Samsuri (2020) Change vegetation density analysis of Sumatran orangutan (Pongo abelii) habitat in Bukit Lawang and Sub-district of Bahorok. IOP Conference Series Earth and Environmental Science 454:012087. DOI: 10.1088/1755-1315/454/1/012087

57. Zaitunah A, Samsuri, Putri A (2019) Landcover change analysis of Besitang watershed, LangkatNorth Sumatra. IOP Conf Ser 1282:012090. DOI:10.1088/1742-6596/1282/1/012090

58. Zaitunah A, Samsuri, Slamet B (2018) Analysis of Greenbelt in Sibolga for tsunami mitigation. IOP Conference Series Earth and Environmental Science 166(1):012028. DOI: 10.1088/17551315/166/1/012028

59. Zaitunah A, Thoha AS, Samsuri, Siregar KI (2019) Analysis of coastal vegetation density changes of Langkat Regency, North Sumatera, Indonesia. IOP Conference Series Earth and Environmental Science 374:012042. DOI: 10.1088/1755-1315/374/1/012042

60. Zaitunah A, Samsuri S, Ahmad AG, Safitri RA (2018) Normalized difference vegetation index (NDVI) analysis for land cover types using Landsat 8 Oli in Besitang watershed, Indonesia. In IOP Conference Series: Earth and Environmental Science (Vol. 126). Institute of Physics Publishing. DO 10.1088/1755 - 1315/126/1/012112

61. Zhang J, Wu H, Cai C (2020) ANNUAL URBAN BUILT-UP CHANGE AREA ONLINE EXTRACTION USING LANDSAT TIME SERIES DATA. The International Archives of the Photogrammetry, Remote Sensing and Spatial Information Sciences, Volume XLIII-B4-2020, 2020 XXIV ISPRS Congress (2020 edition. DOI: 10.5194/isprs-archives-XLIII-B4-2020-735-2020

62. Zhang Y, Wang P, Wang T, Gao Y, Teng M, Li J, Li Z (2020) Using vegetation indices to characterize vegetation cover change in the urban areas of Southern China. Sustainability 12(22):9403.

DOI:10.3390/su12229403

Page $16 / 20$ 
63. Zhou C, Li S, Wang S (2018a) Examining the impacts of urban form on air pollution in developing countries: A case study of China's megacities. International Journal of Environmental Research Public Health, 15(8). DOI:10.3390/ijerph15081565

\section{Figures}

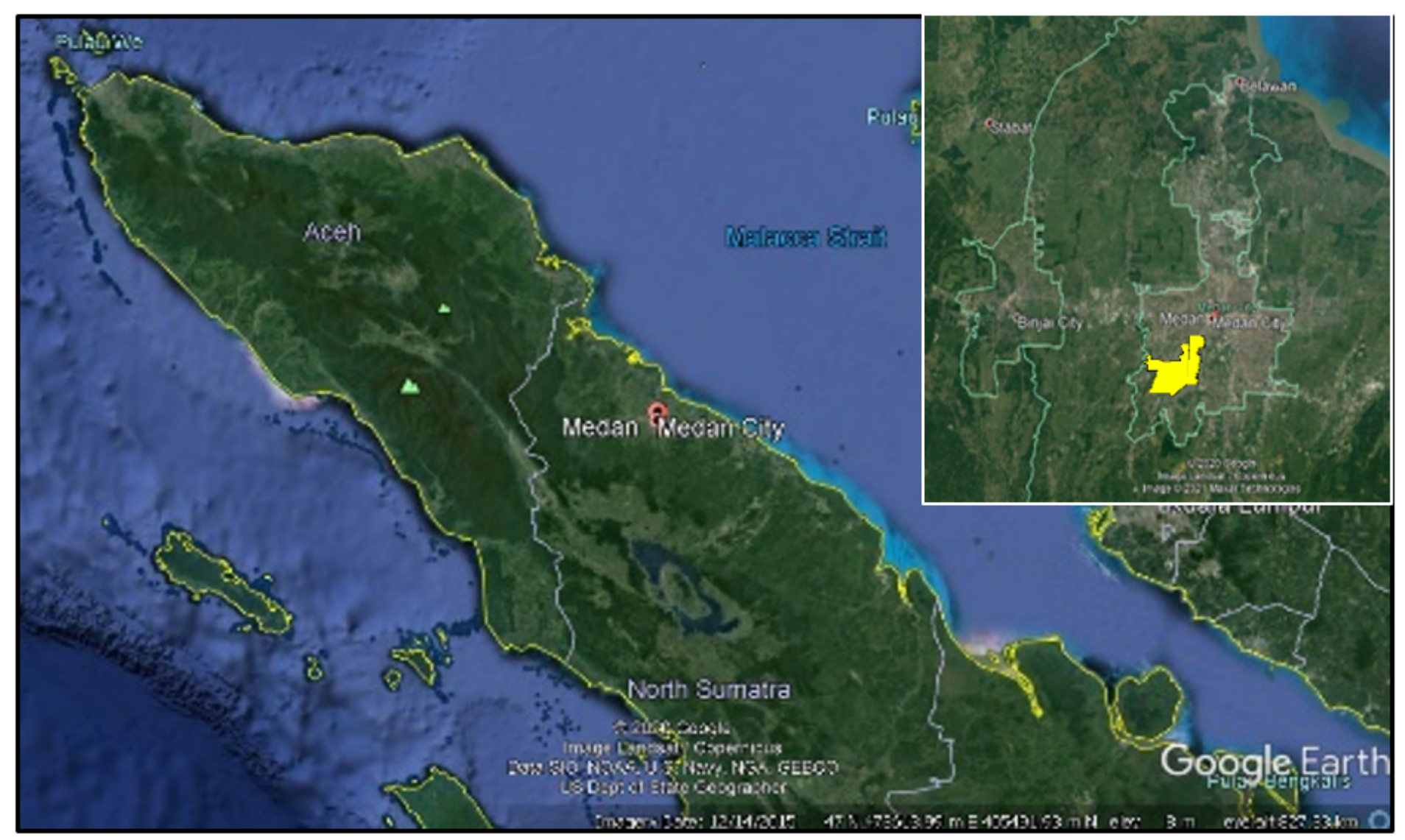

\section{Figure 1}

Research location map. Note: The designations employed and the presentation of the material on this map do not imply the expression of any opinion whatsoever on the part of Research Square concerning the legal status of any country, territory, city or area or of its authorities, or concerning the delimitation of its frontiers or boundaries. This map has been provided by the authors. 


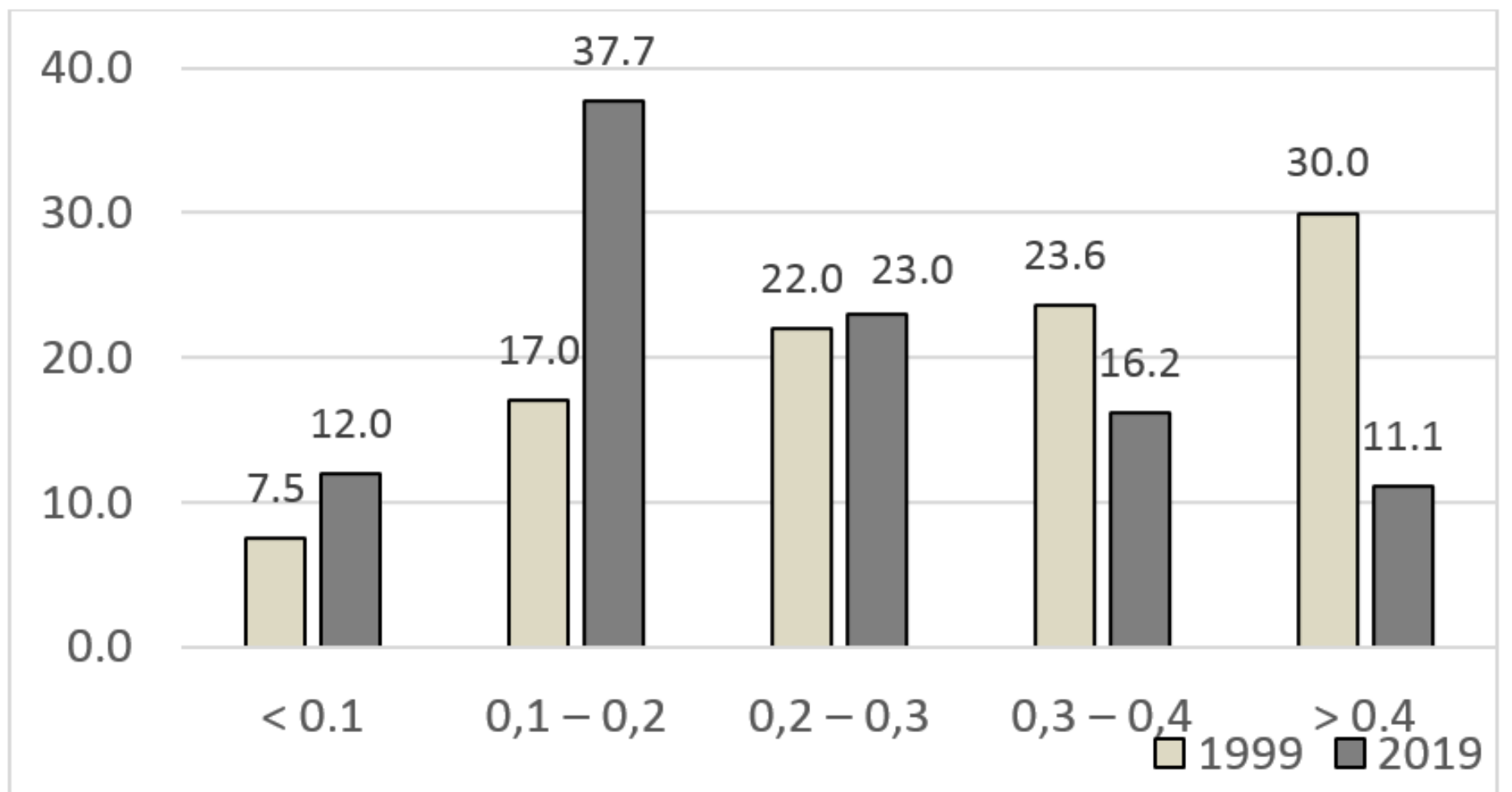

Figure 2

Comparison of areas (\%) in the years 1999 and 2019
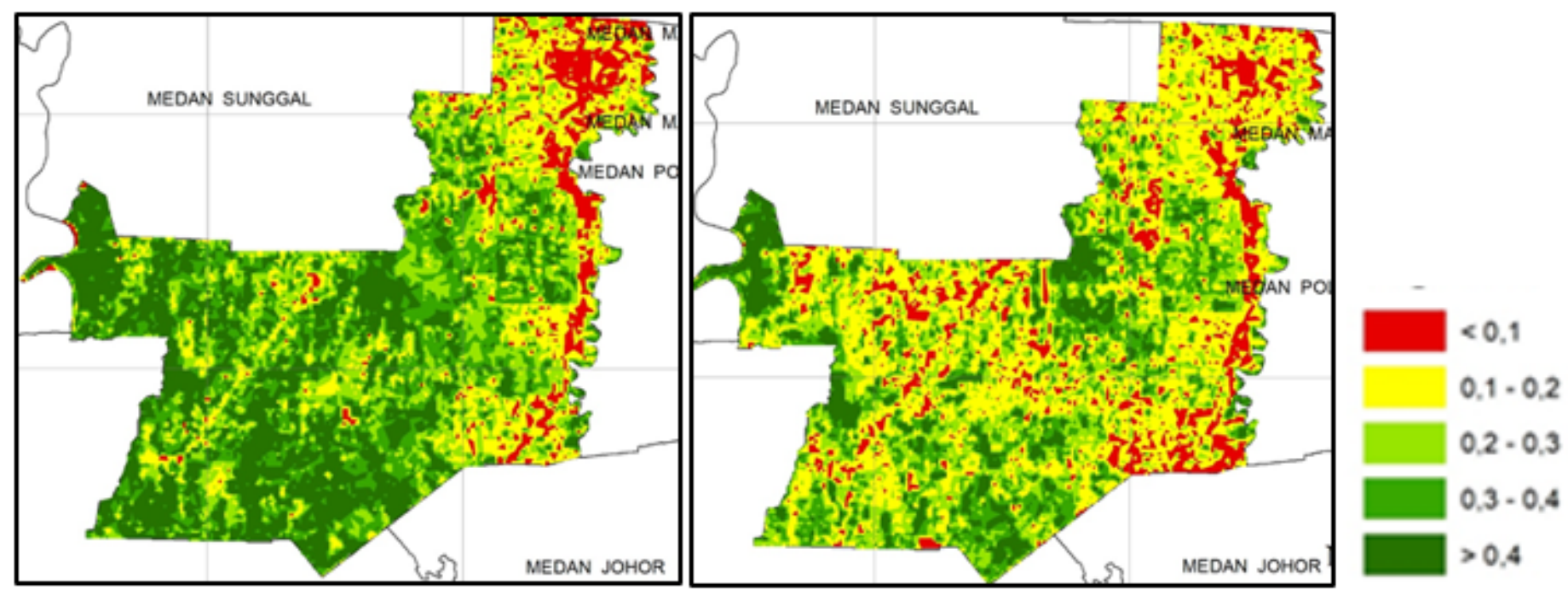

Figure 3

Comparison of the NDVI values between the year 1999 (left) and 2019 (right). Note: The designations employed and the presentation of the material on this map do not imply the expression of any opinion whatsoever on the part of Research Square concerning the legal status of any country, territory, city or 
area or of its authorities, or concerning the delimitation of its frontiers or boundaries. This map has been provided by the authors.
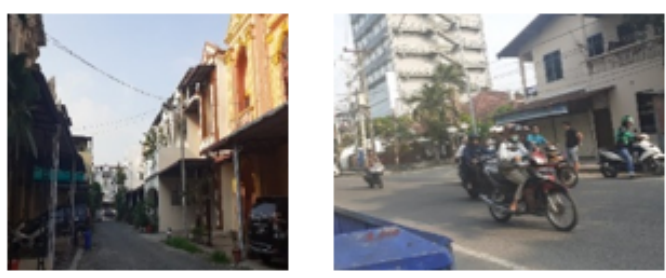

b.

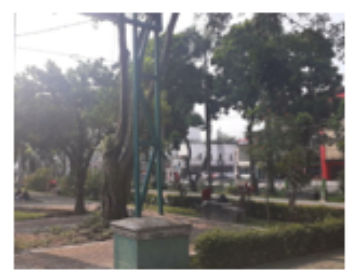

d.

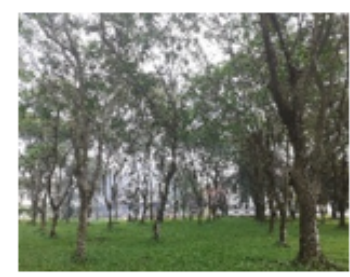

e.

\section{Figure 4}

Visualization of non vegetation (a), medium dense (b), dense (c) and high dense (d) areas in the field.
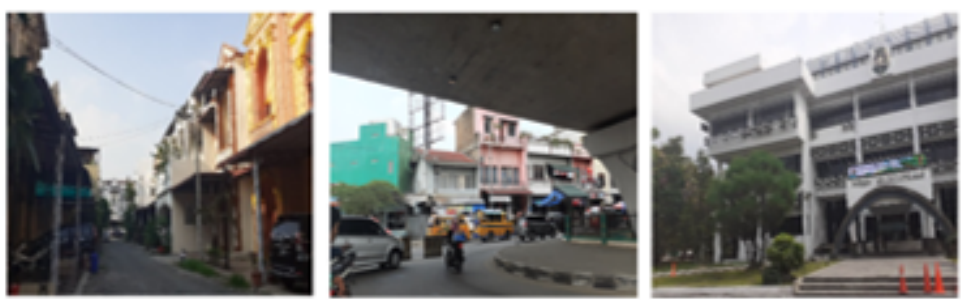

\section{Figure 5}

Non-vegetation class area
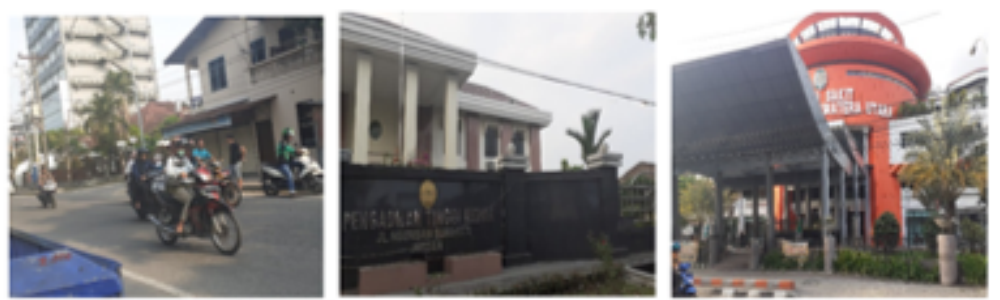

\section{Figure 6}

The low dense class.
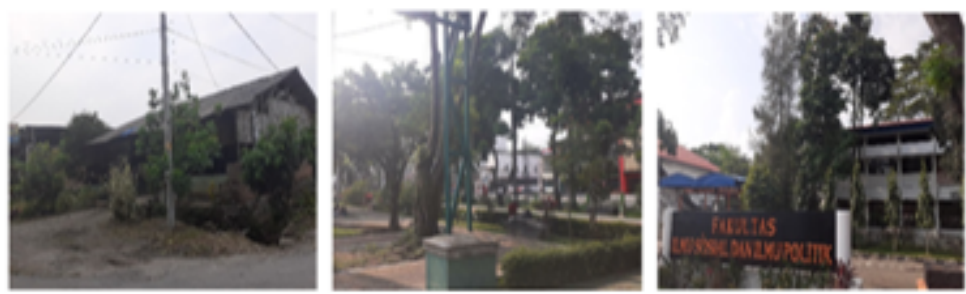

Figure 7 
The medium dense class on-site research
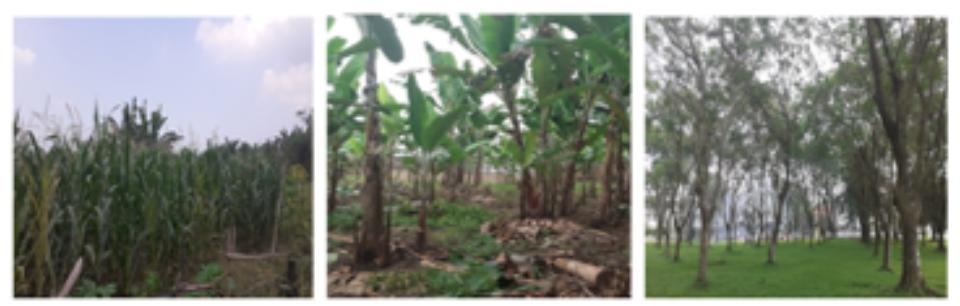

Figure 8

Dense class areas.
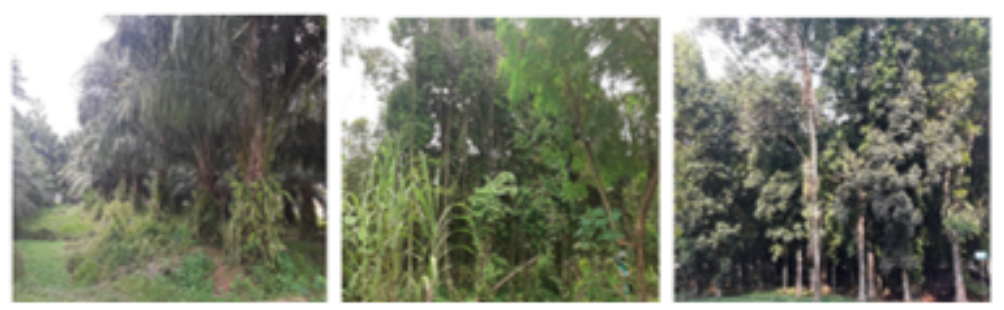

Figure 9

High dense class 